\title{
Family Communication during the 2019 Corona Virus Disease (Covid-19) Pandemic
}

\author{
Puri Kusuma Dwi Putri ${ }^{1^{*}}$ \\ ${ }^{1}$ Dian Nuswantoro University, Semarang, Indonesia
}

Article Information

Submitted February 26, 2021

Revised June 03, 2021

Accepted July 12, 2021

Published October 01, 2021

\begin{abstract}
Conversations among parents and children about the Corona Virus Disease 2019 (Covid-19) and how to prevent the transmission can reduce anxiety and a fear of children about the situation around them. Family communication refers to the verbal and non-verbal word that is happened between family members. Communication involves the ability to pay attention to others about what they think and feel. Communication does not only involve verbal words, but also listens to each other. The purpose of this article was to find out how parent-child communication during the Covid-19 pandemic. The method of this article used literature studies from books, scientific journals, and the internet websites. The results showed that healthy families communicated effectively well, while families with unhealthy relationships had poor communication. The effective communication in the family can be improved by family members through the quality of their relationships, namely frequent communication, communicating clearly and directly, being an active listener, communicating openly and honestly, thinking about people with whom to communicate, paying attention to non-verbal messages, communicating positively, and focus on family strengths. It is better if parents can increase their interaction with their children regarding Covid-19 messages during the pandemic, because it can make an impact on the relationship between parent-child.
\end{abstract}

Keywords: Family communication; interaction; Covid-19 pandemic; parents-children relationship

\section{Introduction}

On 11 March 2020 WHO announced that the spread of the Covid-19 virus is a pandemic. It is recorded that more than 118,000 cases, 114 countries, 4,291 have lost their lives (WHO, 2020b). WHO urged us to stay at home by reducing social interactions and activities outside the home. These can have negative impacts on physical and mental health (WHO, 2020a).
One of ways to prevent the spread of Covid-19 is to stay at home. Some people continue to work through Work from Home, thereby still able to work from their houses. This also applies to children during the pandemic, during which they do not go to school/do activities outside the home. Parents play an important role in assisting their children in their activities of learning (UNICEF, 2020).

\footnotetext{
*Author Correspondence: Puri Kusuma Dwi Putri: purikdp@yahoo.com, Faculty of Computer Science, Dian Nuswantoro University, Jl. Imam Bonjol 207 Semarang 50131, Indonesia
}

Copyright (C) 2021 Puri Kusuma Dwi Putri 
Activities done by children and adolescents while at home show (a) anxiety (24.9\%), depression (19.7\%), and stress (15.2\%). During the closure of schools, $21.4 \%$ of students are more satisfied with their lives. One advantage of school closure is that children self--quarantine at home, allowing parent-child discussions about Covid-19, that can reduce the depression, anxiety, and stress (Tang et al., 2021). Such anxiety, depression, and stress the children and adolescents suffer from did not occur during the pre-pandemic period.

Children become more at home with their parents and are unable to meet friends or engage in outdoor activities. These conditions can cause behavioral changes in children such as temperament/tantrums, developmental delays, overreacting to trivial problems, sleep and eating disorders, excessive crying and irritability, drug abuse for adolescents (Soma, 2020)., the impact of the Covid-19 pandemic increases the risk of child abuse such as physical, mental health, economics, homeschooling challenges, marital conflicts, personal crimes, intensive parent-child relationshipsorang tua-anak (Wu \& Xu, 2020).

Relationship quality is associated with mental health during the lockdown due to COVID-19 (Corona Virus Disease discovered in 2019)(Pieh et al., 2020). Compared to no relations in a relationship, good relationship quality is a protective factor while poor relationship quality is a risk factor in relationships. Parents need to communicate effectively with children regarding lifethreatening diseases, this is beneficial for their psychology in the long term (Dalton et al., 2020).

COVID-19 can be prevented through the process of delivering messages on the dangers of COVID-19 by parents (Kaddi et al., 2020). Thus, families can play their roles and functions optimally and well (Ashidiqie, 2020).

Conversations between parents and their children about Covid-19 and how to prevent its transmission can reduce the children's anxiety and fear and the situation around them. Parents can explain messages on Covid-19 to their children clearly (CDC, 2021).

Good communication is needed within a family to support mutual understanding, reminding each other to stay at home and complying with government policies. The role of communication in a family is to improve good communication among family members. In contrast, the lack of intensive communication may lead to communication dysfunction (Muhid \& Muslimin, 2020). The pandemic has made parents and children physically close, along with psychological closeness, when communication between the two takes place intensively.. Prior to the pandemic,, parents and children were busy with their respective activities, so family communication did not play an optimal role in families. Parents play an important role in influencing the mental health of children in going through the Covid-19 pandemic phase, a condition which did not occur before the pandemic hit (Whittle et al., 2020). The purpose of this article is to examine parentchild communication during the Covid-19 pandemic in the households.

\section{Method}

The method used in writing this article is a literature study or desk study. The literature study was implemented by studying literature 
in the forms of books, scientific journals, and the internet. The main literature references used in this article were obtained through journals.

\section{Findings}

\section{Definition of Family}

The definition of family emphasizes the value of communication in family life and includes the diversity of times. The following are the main themes of the family: the family has form, function, and interaction. Who is in the family and to what purpose are they connected (such as marriage, blood, and adoption). Functions within a family are tasks presented and expected. Meanwhile, the issue of interaction is a process connecting individuals as family members and showing how communication is part of a family (Segrin \& Flora, 2019).

Communication is a process of creating meaning on one another. The axiom of communication consists of (1) communication is a process. Communication shows a dynamic, complexity, and continuous change. In this process, there is a dynamic of creating meaning of the message; (2) communication involves the definition of shared construction. Everyone is unique in communicating and the communication process through discussion; (3) communication is a process involving code. Shared meaning is built using the codes that exist within us. These codes are in the form of verbal and nonverbal communication. Verbal communication is in the form of words used. While nonverbal communication consists of facial expressions, body position, attitude, and communication behavior; (4) communication occurs in a context. Communication requires context in the process of creating meaning.
Context means place, culture, and relation; (5) communication is a transaction. Everyone can be the sender and recipient of messages which are a transaction process in humans; and (6) communication occurs at two levels. All verbal and nonverbal messages can be understood at a level, namely literacy and relationship (Turner \& West, 2012).

Communication is very influential in everyday life. Individuals can develop themselves and build relationships through communication. Individual relationships are built individually or in groups. Relationships of individuals with other individuals can determine the quality of relationships marked with communication effectiveness. Tubbs \& Moss (Rakhmat, 2012); Effective communication is indicated by five important points including: (1) understanding, careful acceptance; (2) pleasure, a warm, intimate and pleasant relationship; (3) influencing attitudes, persuasive; (4) better relations; and (5) action, giving birth to the desired action (Maulana \& Gumelar, 2013).

Interaction is created within families and may occur from outside the families. Conversation is the basis of family life (Handel \& Whitchurch, 2017). Conversations serve two purposes: (1) to inform others about the relationships that other family members have; (2) to explain the values that exist in the families and how to practice them.

Family is a group that defines itself from the intimacy of forming and maintaining its members through interactions among them and with others; a family is an intentional and unintentional relationships; literally forming symbolic internal and external ties; and evolve over time; is history, current, and the future conditions (Turner \& West, 2012). 
A family is not only the foundation of an unit of society, but also the place where individuals physically and mentally grow. A family consists of members of the family. Every family member plays an important role in the process of life in the social system (Dai \& Wang, 2015).

Healthy families communicate effectively, while families with unhealthy relationships communicate poorly. Poor communication within families usually occurs because of many complaints, problems, conflicts, ineffective problem solving, lack of intimacy, and weak emotional bonds (Peterson \& Green, 2009). A study shows that there is a relationship between communication patterns and relationship satisfaction of family members (Noller \& Fitzpatrick, 1990).

Family communication is a communication created in harmony that needs to be pursued by parents and children within families to establish good relationships and avoid problems that can destroy family life (Djamarah, 2014). The communication process within families may run well and may establish interpersonal relationships (Suciati, 2015).

\section{Effective Communication within Families}

Effective communication is an important characteristic of a strong and healthy family. Based on a research, communication is an important building of parent-child relationship (Peterson \& Green, 2009).

Family communication refers to the verbal and non-verbal languages exchanged among family members. Communication involves the ability to pay attention to others regarding what they are thinking and feeling.
Communication does not only involve verbal words, but also listening to each other (Epstein et al., 2003).

Four communication styles that parents need to pay attention to when interacting with their children (Epstein et al., 2003) are: (a) clear and direct delivery. Delivering messages clearly and directly to children shows healthy communication between participants; (b) clear and indirect communication. This communication style delivers clear messages, but it does not directly refer to the targeted person; (c) covert and direct communication. This style of communication delivers messages covertly, but directly, to family members; (d) Covert and indirect communication. Covert and indirect communication exists in messages aimed at unclear recipients. This style of communication usually occurs in families with less healthy relationships.

Effective communication within families can be improved by family members through the quality of their relationships. Ways to establish effective family communication (Peterson \& Green, 2009) are (a) communicating frequently, (b) communicating clearly and directly, (c) being an active listener, (d) communicating openly and honestly, (e) thinking about the person with whom to communicate, (f) paying attention to non-verbal messages, (g) communicating positively, and (h) focusing on family strengths.

The following is the description of how to build effective family communication. (a) communicating frequently. One of the biggest challenges faced by a family is communicating with each other of the family members. Conscious communication is challenging in interacting among the members. There are so many ways family 
members communicate with each other such as during dinner, not turning on the television, taking children to bed, creating an agenda of when communication needs to be made that affects the family; (b) communicating clearly and directly. Healthy families communicate what they think and feel clearly and directly. Problems of the families can be solved through communication between family members. Intimacy and emotional bonding of family members can be enhanced through clear and direct communication.

Further, (c) being an active listener. A family communication skill that need to be improved is active listening. Family members who are active listeners try to understand how other members are feeling. This will show attention between family members verbally and non-verbally. Family members give respect to other family members during the listening process. The process of listening to others consists of three components, namely attention, understanding, and acceptance (Itzchakov \& Grau, 2020). The first component is attention. Attention means the listener gives full attention to the speaker as a sign of non-verbal behavior. The full attention when listening can be shown through eye contact. Messages can be meaningful to listeners when consistent eye contact is made and both look at each other.

The second component of listening is understanding. Understanding means the listener is able to understand what the speaker is saying. This understanding can be confirmed by the speaker through nonverbal communication expressions, verbal communication reflections, and thankful expression. For example, a good listener can ask appropriate questions in accordance with what the speaker is saying. The questions the listener asks are confirmation questions of the messages delivered by the speaker. Good questions by the listener show respect for the speaker, increase interest in and support the speaker's message.

The third component of listening is acceptance. Acceptance shows not judging others and having an open mind. Not judging others means not evaluating what is heard.

Furthermore, (d) communicating openly and honestly. Open and honest communication can be started by a family member to other family members. Strong relationships within the family require mutual trust among its members. Parents have an important role in building trust to their family members (children) to dare to open up about what they think and feel.

Next, (e) thinking about the person with whom to communicate. Family members consist of various ages, from adults to small children. Parents need to pay attention to messages when communicating with children (depending on the children's ages). When parents communicate with young children it is necessary to pay attention to what the children are saying. Parents should pay attention to/respect the time when they are with their children, because children will also pay attention to their parents when they are with them (Kamaruddin, 2012).

Furthermore, (f) paying attention to nonverbal messages. Non-verbal communication is usually more reliable than verbal communication. Family members need to pay attention to non-verbal messages during interactions. What is felt by family members can be delivered through non-verbal communication. Meaningful communication requires a process when interaction takes place. Non-verbal signs (eye contact, smiling, 
and gestures) help communication to be more meaningful and the communication goals can be achieved (Knapp et al., 2014).

Furthermore, (g) communicating positively. Unhappy family relationships show negative communication. Negative communication usually results in criticism, defensiveness, contempt among family members. Dissatisfaction in the family can be shown by communicating negatively between family members. Positive communication between family members can be demonstrated by actively listening to, praising, and encouraging one another.

Next, (h) focusing on family strengths. A healthy family communicates as the key to success in performing family functions. Strong and healthy families communicate clearly, openly, and frequently. Families that are able to solve problems and tend to be satisfied with the relationships among their family members are families with healthy communication.

\section{Impacts of Parent-Child Communication}

The quality of communication is indicated by the interaction between parents and children. Interaction plays an important role in both, because parents can deliver valuable values in life that can bring benefits today or in the future (Runcan et al., 2012).

One of the communication needs between parents and children is the need for affection. The need for affection is the desire to love and to be loved. This need for affection is the idea stated by William Schutz (Wood, 2014). Communication needs between parents and children are in the forms of (1) family functioning through communication;
(2) establishing communication and maintaining relationships between parents and children; (3) parent-child communication becomes stronger and more effective through feedbacks; (4) parents can identify, know, then be satisfied with their children's needs through communication as a motivational process for establishing parent-child relationships. Parent-child communication plays an important role in establishing a balance, effective relationship, understanding and acceptance between both of them (Runcan et al., 2012).

A study in Ethiopia shows that the continuity of interaction and the quality of communication between parents and children can affect children's psychology. The quality of parent-child communication can affect children's welfare (Bireda \& Pillay, 2016).

\section{Discussion}

\section{Message Delivery of Covid-19 between Parents and Children}

Message is anything delivered by a sender to a recipient face to face or through communication media. Messages can be entertainment, information, advice or propaganda, voice, expressions, and gestures (Cangara, 2008).

The main triggers of stress for parents during the Covid-19 lockdown are physical health and mental health. Families can provide education to protect each family member from Covid-19. For example, parents set an example of healthy living during lockdown by wearing masks, social distancing, and also encouraging children to do the same. Parents should have good knowledge about Covid-19 to reduce fear and anxiety in children, and also share emotions about Covid-19 with children 
(Wu \& Xu, 2020).

Parents can start to open up/open communication to their children about the current pandemic situation. Topics to be delivered include, for example, why it is better to stay at home during a pandemic, why it is not allowed to meet many people, why to wear a mask when meeting other people, and so on. According to Altman and Taylor, self-disclosure can start from a relationship that is not intimate at first to an intimate relationship. At the heart of relationship development is self-disclosure. Self-disclosure is the provision of personal information to others (West \& Turner, 2008).

Six ways to deliver messages on Covid-19 by parents to children, based on WHO recommendations, are (1) parents are open and listening. Parents listen to what their children know. Parents can ask their children open-ended questions about what they know; (2) Honest. Parents need to be honest in answering their children. Parents need to know that their children also understand what their parents describe; (3) supportive. A child may be afraid/confused by the events around him or her. Parents serve as a place for children to express what they feel and children know that their parents are there for them; (4) parents can not give right answers. Parents may answer "don't know" to questions from their children, even though parents do not know the answer, parents can answer that they are thinking about it;; (5) not bullying. Covid-19 may infect people of different countries and different languages. We still love those who have contracted the Covid-19 disease. Parents can tell stories of people who helped combat the epidemic and who cared for the sick. Parents who provide answers regarding Covid-19 messages show responsive parenting to children. This is a form of healthy parent-child attention through interaction (Bowlby, 1988) (Karavasilis et al., 2003).

Parents can deliver messages of Covid-19 to their children on how the virus can be transmitted, the importance of social distancing, and the impact of the virus when it enters the human body. Messages on Covid-19 to children are delivered carefully and clearly jelas (Mitchell, 2020).

Parentsneed togetguidanceininteracting with their children about Covid-19. Children also need to get information about what is going on in this world, so most activities should be done at home (Child Mind Institute (CMI), 2021). Some guidelines parents need for communicating about Covid-19 are as follows (UNICEF, WHO, CDC dan Institut Child Mind):

1. Parents are present to accompany children and become leaders.

a. Parents start a conversation with their children about Covid-19. Parents are willing to listen and talk about the current pandemic.

b. Parents ask children how much they know about this pandemic using open-ended questions, listening and building on existing knowledge.

c. Parents ensure that after having a conversation with their children, it doesn't make the children more anxious/fearful.

d. Children can communicate with parents at any time. Parents also continue to provide the latest information regarding the pandemic for their children. 
2. Being wise

a. Parents pay attention to the language used in accordance with the children's ages, observe the children's reaction, and be more sensitive to what the children feel such as their anxiety and understanding.

b. Parents provide information honestly and accurately in accordance with the children's age and developmental level.

c. Parents deliver important information to children such as the importance of keeping hand hygiene.

3. Being calm and peaceful

a. Parents address their concerns regarding anxiety first.

b. Parents acknowledge any concerns their children can have. Concerns of children are addressed first and parents can provide assistance.

c. Parents limit exposure to information of children through radio and television. This is done for children not to be exposed to too much information they do not need.

d. Parents provide information for children that efforts to prevent the Covid-19 outbreak are taken by many people, so that children can follow health protocols properly.

e. Parents deliver information to children that this virus can infect children with moderate symptoms.

4. Parents avoid using language showing stigma

a. Parents explain wisely that everyone can be infected by this virus, without judging their faults.

b. Parents pay attention to their children whether their children receive information about the stigma of people infcted by Covid-19.

5. Parents can be role models

a. Parents act in accordance with what they spoke, not only through conversation.

b. Parents remind their children to avoid the spread of Covid-19 by washing their hands as often as possible.

c. Parents provide information for children so that children avoid people who have the flu/cough.

d. Parents provide information that when children cough/sneeze, they can use a tissue/elbow to cover them so they don't transmit the virus.

e. Parents speak as the facts.

f. Parents can tell that there is hoax news about Covid-19. Hoax news requires confirmation and clarity of information sources first.

g. Parents can search correct and clear information about Covid-19

Based on UNICEF, WHO, CDC and the Child Mind Institute, the following are messages that need to be delivered to children: (a) "what is Covid-19?"; (b) "how is Covid-19 transmitted"; (c) "what happens if someone gets Covid-19?"; (d) "what should I do to avoid getting Covid-19?"; (e) "how can I keep my hands clean"; (f) "what should I do when coughing or other people around us are coughing?"; (g) "What should I do when I feel sick?".

An explanation about Covid-19 by parents will increase children's knowledge of what is going on around them. Children don't go through their usual rhythm since the pandemic was announced by WHO, namely those who previously often did outdoor activities do them at home now, parents work 
from home, children study/school online, the need to maintain health protocols, rarely meet many people, and so forth. The explanation for the questions regarding Covid-19 is as follows: (a) "what is Covid-19?". Covid-19 stands for "coronavirus disease 2019"; (b) "how is Covid-19 transmitted?". The way Covid-19 is transmitted is through viruses existing in the surrounding environment that enter the body. Covid-19 spreads through coughing, sneezing, or may transmits through the items they touch; (c) "what happens if someone gets Covid-19?". If a person is exposed to Covid-19, the symptoms are flu, cough, and shortness of breath; (d) "what should I do to avoid getting Covid-19?". A person can prevent Covid-19 by not touching the mouth, nose and eyes so that the virus does not enter the body. Washing hands before eating and after using the toilet; (e) "how can I keep my hands clean". I can keep my hands clean by washing my hands for at least 20 seconds after sneezing, coughing/sneezing, after using the toilet, and before preparing foods; (f) "what should I do when coughing or other people around us are coughing?" When we cough/sneeze and there are people around us, we should cough/ sneeze into the elbow/use a tissue, then throw it in the trash immediately. We should not cough/sneeze into other people who are too close. We also should not be close to those who are coughing/sneezing; g) "What should I do when I feel sick?". When we feel pain, immediately tell our parents or adults around us.

Based on a study of sensitive and effective communication about a lifethreatening disease that has a long-term psychological impact on children and their families, a scholar from the University of Oxford provides guidance on parent-child interactions regarding the Covid-19 message. The following are the principles that parents need to pay attention to (Department of Psychiatry, 2021), namely: (1) parents need to deliver information honestly about the changes experienced by the family. When there is no parent-child communication, children will try to understand, on their own, the situation going on around them; (2) the children's developmental stages help communicate more effectively; (3) children need to understand cases of disease that occur around them, not just being told in simple language.

\section{Conclusion}

The Covid-19 pandemic has made parents meet more often with their family members. So, it is expected that the intensity of the interaction will increase. Parents also need to limit the media coverage of hoaxes about Covid-19. Reports in the media show that the world is experiencing an epidemic leading to death. A child can still feel what is going on around him or her.

Findings of this study show that effective communication within families can be improved by family members through the quality of their relationships, namely communicating frequently, communicating clearly and directly, being active listeners, communicating openly and honestly, thinking about the person with whom to communicate, paying attention to non-verbal messages, communicating positively, and focusing on family strengths. Parents should be able to increase their interaction with their children regarding Covid-19 messages, because it can affect the relationship between parents and children. 
Based on a study of sensitive and effective communication on life-threatening diseases has long-term psychological impacts on children and their families, parents should be able to follow guidelines on how to interact with children regarding the Covid-19 topic, to increase interaction between the two because it has an impact on mental health, parents should be able to start opening up/ opening communication to children about the pandemic situation they are experiencing, such as why during the pandemic it is better to stay at home, why they should not meet many people, why they should wear a mask while meeting other people, and maintain other health protocols. Parents' communication style can be by delivering messages that are (a) clear and direct; (b) clear and indirect, (c) covert and direct; (d) covert and indirect. A healthy parent-child relationship will lead to communication satisfaction between the two. Family communication is important so that families can perform their functions and roles well. Families as the smallest unit in society should initiate healthy parentchild communication in order to prevent the negative impacts that occur during the pandemic.

\section{Reference}

Ashidiqie, M. L. I. I. (2020). Peran Keluarga Dalam Mencegah Corona Virus Disease 2019. Jurnal Sosial Dan Budaya Syar'i, 7(10), 911-922. https://doi. org/10.15408/sjsbs.v7i8.15411

Bireda, A. D., \& Pillay, J. (2016). Perceived parent-Child Communication and WellBeing Among Ethiopian Adolescents. International Journal of Adolescence and Youth, 23(1), 109-117. https://doi.org/

$$
\text { 10.1080/02673843.2017.1299016 }
$$

Bowlby, J. (1988). A Secure Base: ParentChild Attachment and Healthy Human Development. Basic Books. https:// www.increaseproject.eu/images / DOWNLOADS/IO2/HU/CURR_M4-A13_ Bowlby_(EN-only)_20170920_HU_final. pdf

Cangara, H. (2008). Pengantar Ilmu Komunikasi. PT Raja Grafindo Persada.

CDC. (2021). Families and COVID-19. Centers for Disease Control and Prevention (CDC).

Child Mind Institute (CMI). (2021). Family Resource Center. Childmind.Org. https:// childmind.org/

Dai, L., \& Wang, L. (2015). Review of Family Functioning. Open Journal of Social Sciences, 03(12), 134-141. https://doi. org/10.4236/jss.2015.312014

Dalton, L., Rapa, E., \&Stein, A.(2020). Protecting The Psychological Health of Children Through Efective Communication About COVID-19. Lancet Child Adolescent Health, 4(5), 346-347. https://doi. org/10.1016/S2352-4642(20)30097-3

Department of Psychiatry, W. H. (2021). The Importance of Communication to Children. Department of Psychiatry Oxford University. https://www.psych. ox.ac.uk/research/covid_comms_ support/families/the-importance-ofcommunication-to-children

Djamarah, S. B. (2014). Pola Asuh Orang Tua dan Komunikasi dalam Keluarga. PT Rineka Cipta.

Epstein, N. B., Ryan, C. E., Bishop, D. S., Miller, I. W., \& Keitner, G. I. (2003). The McMaster Model View of Healthy 
Family Functioning. In F. Walsh (Ed.), Normal family processes: Growing diversity and complexity (pp. 581607). The Guilford Press. https:// doi.org/10.4324/9780203428436_ chapter_21

Handel, G., \& Whitchurch, G. G. (2017). The psychosocial interior of the family. In Routledge. Routledge.

Itzchakov, G., \& Grau, J. (2020). High-Quality Listening in the age of COVID-19: A key to better dyadic communication for more effective organizations. Organizational Dynamic. https://doi.org/10.1016/j. orgdyn.2020.100820

Kaddi, S. M., Lestari, P., \& Adrian, D. (2020). Komunikasi Keluarga dalam Pencegahan Coronavirus Disease 2019. Jurnal Ilmu Komunikasi, 18(1), 63-74. https://doi. org/10.31315/jik.v18i1.3701

Kamaruddin, S. A. (2012). Character Education and Students Social Behavior. Journal of Education and Learning (EduLearn), 6(4), 223. https://doi.org/10.11591/ edulearn.v6i4.166

Karavasilis, L., Doyle, A. B., \& Markiewicz, D. (2003). Associations Between Parenting Style and Attachment to Mother in Middle Childhood and Adolescence. International Journal of Behavioral Development, 27(2), 153-164. https:// doi.org/10.1080/0165025024400015

Knapp, M. L., Hall, J. A., \& Horgan, T. G. (2014). Nonverbal Communication in Human Interaction. Wadsworth Cengage Learning.

Maulana, H., \& Gumelar, G. (2013). Psikologi Komunikasi dan Persuasi. Akademia Pratama.
Mitchell, F. (2020). Communicating With Children About COVID-19. The Lancet Infectious Disease, 20(9), 1023. https://doi.org/10.1016/S14733099(20)30626-5

Muhid, A., \& Muslimin, M. (2020). Studi Literature: Peranan Komunikasi dalam Keluarga Dimasa Pandemi Covid-19. HIKMAH, 14(2), 185-198.

Noller, P., \& Fitzpatrick, M. A. (1990). Marital Communication in The Eighties. Journal of Marriage and the Family, 52, 832-843. https://doi.org/10.2307/353305

Peterson, R., \& Green, S. (2009). Families First: Keys to Successful Family Functioning Communication. Virginia Cooperative Extension (VCE). http://hdl.handle. net/10919/48300

Pieh, C., O’Rourke, T., Budimir, S., \& Probst, T. (2020). Relationship Quality and Mental Health During COVID-19 Lockdown. PLOS ONE, 16(9). https:// doi.org/10.1371/journal.pone.0238906

Rakhmat, J. (2012). Psikologi Komunikasi. Remaja Rosda Karya.

Runcan, P. L., Constantineanu, C., Ielics, B., \& Popa, D. (2012). The Role of Communication in The ParentChild Interaction. Procedia - Social and Behavioral Sciences, 46, 904 - 908. https://doi.org/10.1016/j. sbspro.2012.05.221

Segrin, C., \& Flora, J. (2019). Family Communication. Routledge.

Soma, G. J. (2020). Communicating to children About The COVID-19 Pandemic. South Sudan Medical, 13(2), 60-63. http:// www.southsudanmedicaljournal.com/ archive/may-2020/communicating-to- 
children-about-the-covid-19-pandemic. html

Suciati. (2015). Komunikasi Interpersonal: Sebuah Tinjauan Psikologis dan Perspektif Islam. Buku Litera Mata Padi Persindo.

Tang, S., Xiang, M., Cheung, T., \& Xiang, Y.-T. (2021). Mental health and its correlates among children and adolescents during COVID-19 school closure: The importance of parent-child discussion. Journal of Affective Disorders, 279, 353-360. https://doi.org/10.1016/j. jad.2020.10.016

Turner, L., \& West, R. (2012). Perspective on Family Communication. McGrawHill.

UNICEF. (2020). Recommendations to families on how to combine working from home with caring for young children. https:// www.unicef.org/lac/media/11251/file/ Teleworking-and-caring-for-children. pdf

West, R., \& Turner, L. H. (2008). Pengantar Teori Komunikasi. Analisis dan Aplikasi. Salemba.
Whittle, S., Bray, K., Lin, S., \& Schwartz, 0. (2020). Parenting and child and adolescent mental health during the COVID-19 pandemic. https://doi. org/10.31234/osf.io/ag2r7

WHO. (2020a). \#HealthyAtHome - Healthy parenting. World Health Organization. https://www.who.int/campaigns/ connecting-the-world-to-combatcoronavirus / healthyathome / healthyathome---healthy-parenting

WHO. (2020b). WHO Director-General's opening remarks at the media briefing on COVID-19 - 11 March 2020. World Health Organization. https://www. who.int/director-general/speeches/ detail/who-director-general-s-openingremarks-at-the-media-briefing-oncovid-19---11-march-2020

Wood, J. T. (2014). Komunikasi Interpersonal. Salemba Humanika.

Wu, Q., \& Xu, Y. (2020). Parenting Stress and Risk of Child Maltreatment During The COVID-19 Pandemic: A family Stress Theory Informed Perspective. Developmental Child Welfare, 2(3), 180-196. https://doi. org/10.1177/2516103220967937 